\title{
MAKALAH
}

\section{Manajemen Sarana dan Prasarana Pendidikan}

Diajukan sebagai salah satu tugas Mata Kuliah Manajemen Sekolah

\section{Dosen :}

Wahyu Bagja Sulfemi, S.S., M. Pd.

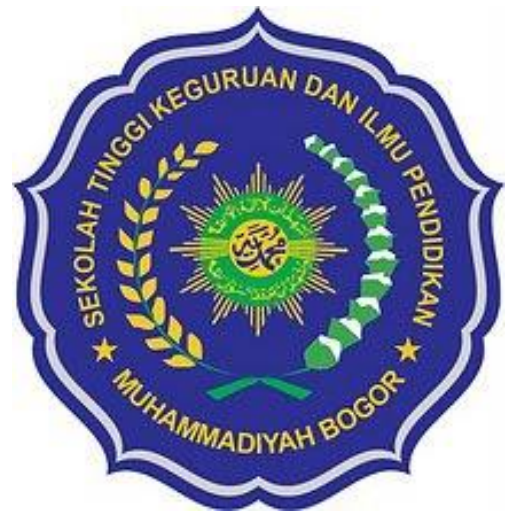

Disusun Oleh :

SRI RAHAYU

NIM 0142S1A018006

\section{PROGRAM STUDI ADMINISTRASI PENDIDIKAN STKIP MUHAMMADIYAH BOGOR}

Jl. Raya Leuwiliang No. 106 Bogor 16640 Telepon : (0251) 8644743, Faks : (0251) 8642847 e-mail :stkipm_bogor@yahoo.com 


\begin{abstract}
Abstrak
Tulisan ini mengkaji mengenai manajemen sarana dan prasarana pendidikan. Metode dalam penulisan ini adalah mengkaji tentang pengertian, dan pentingkah sarana dan prasarana pendidikan di sekolah untuk menunjang kegiatan belajar mengajar. Dengan demikian sarana pendidikan dan prasarana pendidikan adalah pada fungsi masing-masing yaitu: sarana pendidikan untuk memudahkan dalam penyampaian materi ajar, dalam artian segala macam peralatan yang digunakan guru dan murid untuk memudahkan penyampaian dan penerimaan materi pelajaran. Sedangkan prasarana pendidikan adalah untuk memudahkan penyelenggaraan pendidikan dalam artian segala macam peralatan, kelengkapan, dan benda-benda yang digunakan guru dan murid untuk memudahkan penyelenggaraan pendidikan.
\end{abstract}




\section{KATA PENGANTAR}

Assalamu'alaikum Warahmatullahi Wabarakatuh.

Alhamdulillah puji syukur kehadirat Allah SWT yang telah melimpahkan rahmat, rizki dan hidayah-Nya, sehingga penulis dapat menyelesaikan makalah ini. Adapun penyusunan makalah ini bertujuan untuk memenuhi tugas mata kuliah Manajemen Sekolah, di Sekolah Tinggi Keguruan dan Ilmu Pendidikan (STKIP) Muhammadiyah Bogor, terutama mahasiswa program studi Administasi Pendidikan semester III. Mata kuliah Manajemen Sekolah adalah mata kuliah wajib dengan beban 2 sks.

Keberhasilan penulis dalam menyelesaikan makalah ini tidak lepas dari bantuan dan partisipasi berbagai pihak. Untuk itu penulis ingin menyampaikan ucapan terima kasih kepada :

1. Pimpinan STKIP Muhammadiyah Bogor.

2. Ketua Program Studi Administasi Pendidikan.

3. Dosen pengampu Wahyu Bagja Sulfemi, S,S., M.Pd.

4. Kepada Seluruh Dosen dan Staf STKIP Muhammadiyah Bogor.

5. Kedua Orang Tua tercinta.

6. Mahasiswa Program Studi Administrasi Pendidikan STKIP Muhammadiyah Bogor.

Semoga Allah SWT membalas kebaikan dan ketulusan semua pihak yang telah membantu menyelesaikan makalah ini dengan melimpahkan rahmat dan karuni-Nya. Dalam penyusunan karya tulis ini, penulis menyadari masih ada kekurangan dan masih jauh dari kata sempurna. Oleh karena itu kritik dan saran yang masih sifatnya membangun dari semua pihak sangat penulis harapkan. Semoga makalah ini dapat memberikan manfaat dan kebaikan bagi banyak pihak demi kemaslahatan bersama, serta bernilai ibadah dihadapan Allah SWT. Aamiin.

Wassalamu’alaikum Warahhmatullahi Wabarakatuh.

Bogor, November 2019

Penulis 


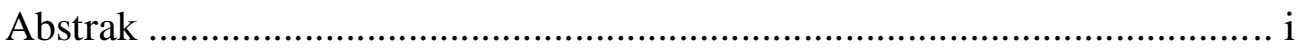

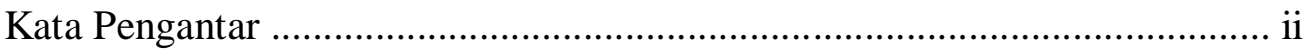

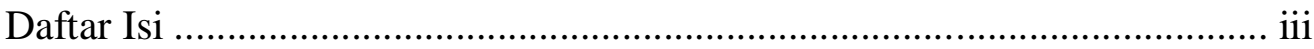

\section{BAB I PENDAHULUAN}
A. Latar Belakang
1

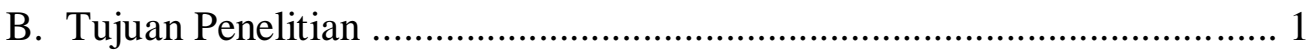

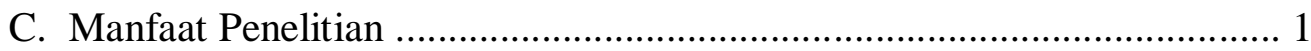

\section{BAB II LANDASAN TEORI}

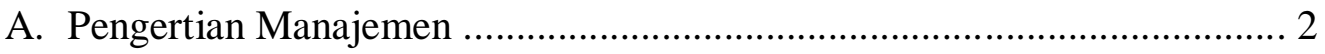

B. Pengertian Sarana dan Prasarana ............................................................. 3

C. Pengertian Pendidikan .......................................................................... 3

D. Pengertian Manajemen Sarana dan Prasarana Pendidikan ........................ 4

\section{BAB III PEMBAHASAN}

A. Jenis-Jenis dan Fungsi Sarana dan Prasarana Pendidikan .......................... 6

B. Pengelolaan Sarana dan Prasarana Pendidikan .......................................... 8

C. Pengaruh Sarana dan Prasarana Pendidikan Dalam Menunjang Kualitas Siswa

D. Pentingnya Sarana dan Prasarana Pendidikan ......................................... 9

\section{BAB IV SOAL DAN JAWABAN}
A. Pilihan Ganda
B. Essay 13
C. Jawaban

\section{BAB V PENUTUP}
A. Kesimpulan 16
B. Saran 16
Daftar pustaka 17 


\section{BAB I}

\section{PENDAHULUAN}

\section{A. Latar Belakang}

Secara tidak langsung sarana dan prasarana yang ada di sekolah menjadi bagian terpenting yang harus diadakan keberadaannya. Kualitas sebuah sekolah juga dapat di lihat dari segi kelengkapan sarana prasarana yang di miliki, karena sarana prasarana yang ada akan sangat menunjang proses belajar, akademik maupun non akademik. Oleh sebab itu perlu adanya upaya pengadaan sarana dan prasarana yang layak agar kegiatan pembelajaran berjalan baik dan memberikan hasil yang maksimal.

\section{B. Tujuan Penelitian}

a. Supaya pembaca mengetahui apa itu Manajemen Sarana dan Prasarana Pendidikan yang ada di sekolah.

b. Agar pembaca bisa memahami tentang Sarana dan Prasarana.

c. Supaya pembaca mengetahui seberapa pentingnya sarana dan prasarana dalam menunjang kegiatan belajar mengajar.

\section{Manfaat Penelitian}

Makalah ini dibuat agar dapat dijadikan panduan bagi para pembaca terkhusus bagi diri saya sendiri umumnya bagi orang lain. Dengan adanya makalah ini yang berjudul "MANAJEMEN SARANA DAN PRASARANA PENDIDIKAN" mampu menjadi pedoman bagi seluruh sekolah yang ada di Indonesia. Yang di mana sarana dan prasarana mencakup keseluruhan proses perencanaan pengadaan, pendayagunaan, dan pengawasan sarana dan prasarana yang digunakan agar tujuan pendidikan di sekolah dapat tercapai dengan efektif dan efisien. 


\section{BAB II \\ LANDASAN TEORI}

\section{A. Pengertian Manajemen}

Manajemen adalah strategi pemanfaatan tenaga dan pikiran orang lain untuk melaksanakan suatu aktivitas yang diarahkan pada pencapaian tujuan yang telah ditentukan sebelumnya. Dalam manajemen terdapat ternik-teknik yang kaya dengan estetika kepemimpinan salam mengarahkan, memengaruhi mengawasi, dan mengorganisasikan semua komponen yang saling menunjang untuk tercapainya tujuan. (Manajemen Pendidikan Berbasis Multi Media, Sulfemi, Wahyu Bagja. 2019 : 1)

Manajemen adalah proses bekerja sama antara individu dan kelompok serta sumber daya lainnya dalam mencapai tujuan organisasi adalah sebagai aktivitas majerial. (Manajemen Kurikulum, Sulfemi, Wahyu Bagja. $2018: 3$ )

Manajemen berasal dari kata to mange yang berarti mengelola. Pengelolaan dilakukan melalui proses dan dikelola berdasarkan urutan dan fungsi-fungsi manajemen itu sendiri. Manajemen adalah melakukan pengelolaan sumberdaya yang dimiliki oleh sekolah/organisasi yang diantaranya adalah manusia, uang, metode, material, mesin, dan pemasaran yang dilakukan dengan sistematis dalam suatu proses. (Manajemen Sekolah, Rohiat, 2010 : 14)

Pengeloaan tersebut dilakukan untuk mendayagunakan sumberdaya yang dimiliki secara terintegrasi dan terkoordinasi untuk mencapai tujuan sekolah/organisasi. Pengelolaan dilakukan oleh kepala sekolah dengan kewenangannya sebagai manajer sekolah melalaui komando-komando atau keputusan-keputusan yang telah ditetapkan dengan mengarahkan sumberdaya untuk mencapai tujuan. 


\section{B. Pengertian Sarana dan Prasarana}

Sarana adalah semua fasilitas yang diperlukan dalam proses belajar mengajar, baik yang bergerak maupun yang tidak bergerak agar pencapaian tujuan pendidikan berjalan dengan lancar, teratur, efektif dan efisien.

Prasarana adalah fasilitas yang secara tidak langsung menunjang jalannya proses pendidikan, seperti: halaman, kebun atau taman sekolah, jalan menuju ke sekolah, tata tertib sekolah, dan sebagainya.

Sarana dan prasarana merupakan suatu alat atau bagian yang memiliki peran sangat penting bagi keberhasilan dan kelancaran suatu proses, termasuk juga dalam lingkup pendidikan. Sarana dan prasarana adalah fasilitas yang mutlak dipenuhi untuk memberikan kemudahan dalam menyelenggarakan suatu kegiatan walaupun belum bisa memenuhi sarana dan prasarana dengan semestinya.

\section{Pengertian Pendidikan}

Pendidikan merupakan usaha sadar dan terencana dalam mewujudkan proses pembelajaran dan suasana belajar agar peserta didik secara aktif mengembangkan potensi diri untuk memiliki kekuatan spiritual, keagamaan, pengendalian diri, kecerdasan, kepribadian, berakhlak mulia, serta memiliki keterampilan yang diperlukan peserta didik, bermasyarakat, bangsa dan negara. (Meningkatkan hasil belajar peserta didik kelas 3 SD menggunakan model picture and picture dan media gambar seni, Sulfemi, Wahyu Bagja. 2018 : 229)

Pendidikan (education) adalah secara semantik berasal dari bahasa Yunani Paidagogia yang berarti pergaulan dengan anak-anak. Pedagogos adalah seorang nelayan atau bujang dalam zaman Yunani kuno yang pekerjaannya menjemput dan mengantar anak-anak ke dan dari sekolah. Selain itu, di rumahnya anak tersebut selalu dalam pengawasan dan penjagaan para paedagogos. Istilah ini berasal dari kata paedos yang berarti anak, dan agogos yang berarti saya membimbing atau memimpin. 
(Modul Manajemen Pendidikan Non Formal. Sulfemi, Wahyu Bagja. 2018 :1)

\section{Manajemen Sarana dan Prasarana Pendidikan}

Manajemen Sarana dan Prasarana pendidikan adalah kegiatan yang mengatur untuk mempersiapkan segala peralatan/material bagi terselenggaranya proses pendidikan di sekolah. Manajemen sarana dan prasarana dibutuhkan untuk membantu kelancaran proses belajar mengajar. Sarana dan prasarana pendidikan adalah semua benda bergerak dan tidak bergerak yang dibutuhkan untuk menunjang penyelenggaraan kegiatan belajar mengajar, baik secara langsung maupun tidak langsung. (Manajemen Sekolah. Rohiat. 2010 : 26)

Manajemen sarana dan prasarana merupakan keseluruhan proses perencanaan pengadaan, pendayagunaan, dan pengawasan sarana dan prasarana yang digunakan agar tujuan pendidikan di sekolah dapat tercapai dengan efektif dan efisien. Kegiatan manajemen sarana dan prasarana meliputi :

1. Perencanaan

Perencanaan merupakan suatu proses kegiatan menggambarkan sebelumnya hal-hal yang akan dikerjakan kemudian dalam rangka mencapai tujuan yang telah ditetapkan. Dalam hal ini perencanaan yang dimaksud adalah merinci rancangan pembelian, pengadaan, rehabilitasi, distribusi atau pembuatan peralatan dan perlengkapan sesuai dengan kebutuhan. Dengan demikian perencanaan sarana dan prasarana pendidikan dapat didefinisikan sebagai keseluruhan proses perkiraan secara matang rancangan pembelian, pengadaan, rehabilitasi, distribusi atau pembuatan peralatan dan perlengkapan yang sesuai dengan kebutuhan sekolah.

2. Pengadaan

Pengadaan merupakan serangkaian kegiatan menyediakan berbagai jenis sarana dan prasarana pendidikan sesuai dengan kebutuhan untuk 
mencapai tujuan pendidikan. Kebutuhan sarana dan prasarana dapat berkaiatan dengan jenis spesifikasi, jumlah,waktu, tempat, harga serta sumber yang dapat dipertanggungjawabkan. Pengadaan dilakukan sebagai bentuk realisasi ats perencanaan yang telah dilakukan sebelumnya. Tujuannya untuk menunjang proses pendidikan agar berjalan efektif dan efisien sesuai dengan tujuan yang di inginkan.

3. Penyimpanan

Penyimpanan sarana dan prasarana adalah kegiatan yang dilakukan oleh satuan kerja atau petugas gudang untuk menampung hasil pengadaan barang atau bahan kantor baik berasal dari pembelian, instansi lain, atau diperoleh dari bantuan.

4. Pemeliharaan

Pemeliharaan merupakan kegiatan penjagaan atau pencegahan dari kerusakan suatu barang, sehingga barang tersebut kondisinya baik dan siap digunakan. Pemeliharaan mencakup segala daya upaya yang terus menerus untuk mengusahakan agar peralatan tersebut tetap dalam keadaan baik. Pemeliharaan dimulai daripemakaian barang, yaitu dengan cara hati-hati dalam menggunakannya. Pemeliharaan yang bersifat khusus harus dilakukan oleh petugas yang mempunyai keahlian sesuai dengan jenis barang yang dimaksud

5. Penghapusan sarana dan prasarana pendidikan

Penghapusan barang adalah kegiatan akhir dari siklus pengelolaan sarana dan prasarana yang dilakukan dengan menggunakan mekanisme tertentu, berdasarkan peraturan dan ketentuanyang berlaku. Tujuan penghapusan sarana dan prasarana adalah untuk membebaskan bendaharawan barang atau pengelola dari pertanggung jawaban administrasi dan fisik atas barang milik negara yang berada di bawah atau pengurusannya sesuai dengan perundang-undangan yang berlaku. 


\section{BAB III \\ PEMBAHASAN}

\section{A. Jenis-Jenis dan Fungsi Sarana dan Prasarana Pendidikan}

Fasilitas pengajaran (sarana dan prasarana) dan kompetensi profesional yang dimiliki oleh seorang guru pada dasarnya mempunyai tujuan yang sama yakni bagaimana membuat siswa merasa nyaman dan dapat memotivasi siswa dalam belajar, sehingga proses belajar dapat berjalan dengan lancar dan berhasil sesuai yang diharapkan yaitu dapat meningkatkan prestasi siswa. Sarana pendidikan diklasifikasikan menjadi tiga macam, yaitu: habis tidaknya dipakai, bergerak tidaknya pada saat digunakan, dan ditinjau dari hubungannya dengan proses belajar mengajar.

1. Ditinjau dari Habis Tidaknya Dipakai

Dilihat dari habis tidaknya dipakai, ada dua macam sarana pendidikan, yaitu: sarana pendidikan yang habis dipakai dan sarana pendidikan tahan lama.

a. Sarana pendidikan yang habis dipakai adalah segala bahan atau alat yang apabila digunakan bisa habis dalam waktu yang relatif singkat. Contoh: kapur tulis, beberapa bahan kimia untuk guru dan siswa praktik, dan sebagainya. Selain itu, ada sarana pendidikan yang berubah bentuk, misalnya kayu, besi, dan kertas karton yang sering digunakan oleh guru dalam mengajar. Contoh: pita mesin ketik/komputer, bola lampu, dan kertas.

b. Sarana pendidikan tahan lama adalah keseluruhan bahan atau alat yang dapat digunakan secara terus menerus dan dalam waktu yang relatif lama. Contohnya: bangku sekolah, mesin tulis, atlas, globe, dan beberapa peralatan olahraga.

2. Bergerak Tidaknya Saat Digunakan

Ditinjau dari bergerak tidaknya pada saat digunakan ada dua macam sarana pendidikan, yaitu: sarana pendidikan yang bergerak dan sarana pendidikan tidak bergerak. 
a. Sarana pendidikan yang bergerak adalah sarana pendidikan yang bisa digerakan atau dipindah sesui dengan kebutuhan pemakainya.. Contoh: Almari arsip sekolah, bangku sekolah, dll.

b. Sarana pendidikan yang tidak bisa bergerak adalah semua sarana pendidikan yang tidak bisa atau relatif sangat sulit untuk dipindahkan. Contoh: saluran dari Perusahaan Daerah Air Minum (PDAM).

3. Ditinjau dari hubungannya dengan Proses Belajar Mengajar

Sarana pendidikan dibedakan menjadi 3 macam bila ditinjau dari hubungannya dengan proses belajar mengajar, yaitu: alat pelajaran, alat peraga, dan media pengajaran.

a. Alat pelajaran adalah alat yang digunakan secara langsung dalam proses belajar mengajar, misalnya: buku, alat tulis, dan alat praktik.

b. Alat peraga adalah alat pembantu pendidikan dan pelajaran, dapat berupa benda-benda yang mudah memberi pengertian kepada anak didik berturut-turut dari yang abstrak sampai dengan yang konkret.

c. Media pengajaran adalah sarana pendidikan yang digunakan sebagai perantara dalam proses belajar mengajar, untuk lebih mempertinggi efektivitas dan efisiensi dalam mencapai tujuan pendidikan. Ada tiga jenis media, yaitu: media audio, media visual, dan media audio visual.

Adapun prasarana pendidikan di sekolah bisa di klasifikasikan menjadi dua macam, yaitu:

1. Prasarana pendidikan yang secara langsung digunakan untuk proses belajar mengajar. Contoh: ruang teori, ruang perpustakaan, ruang praktik keterampilan, dan ruang laboratorium.

2. Prasarana sekolah yang keberadaannya tidak digunakan untuk proses belajar mengajar, tetapi secara langsung sangat menunjang terjadinya proses belajar mengajar. Contohnya: ruang kantor, kantik, tanah dan 
jalan menuju sekolah, kamar kecil, ruang tata usaha, ruang UKS, ruang guru, ruang kepala sekolah, dan tempat parkir kendaraan.

\section{B. Pengelolaan Sarana dan Prasarana Pendidikan}

1. Perencanaan sarana pendidikan

Penentuan kebutuhan merupakan perencanaan pengadaan sarana pendidikan yang diperlukan dalam penyelenggaraan pendidikan. Sebelum mengadakan alat-alat tertentu atau fasilitas pendidikan terlebih dahulu harus melalui prosedur yang benar, yaitu melihat dan memeriksa kembali keadaan dan kekayaan yang telah ada, agar tidak terjadi sarana pendidikan yang mubazir, seperti pengadaan kembali sarana yang masih memadai dari segi kuantitas maupun kualitas atau pengadaan alat-alat yang tidak diperlukan dalam penyelenggaraan pendidikan. Setelah melalui prosedur yag benar, baru bisa ditentukan jenis sarana yang diperlukan berdasarkan kepentingan pendidikan di sekolah.

2. Penyimpanan Sarana Dan Prasarana Pendidikan

Penyimpanan adalah kegiatan yang dilakukan untuk menampung hasil pengadaan dan umumnya barang tersebut adalah milik negara pada wadah/tempat yang telah disediakan. Penyimpanan sarana dan prasarana pendidikan adalah kegiatan menyimpan suatu barang baik beruapa perabot, alat tulis kantor, surat-surat maupun barang elektronik dalam keadaan baru ataupun sudah rusak yang dapat dilakukan oleh beberapa orang yang ditunjuk atau ditugaskan pada lembaga pendidikan. Aspek yang perlu diperhatikan dalam penyimpanan adalah aspek fisik dan aspek administratif.

3. Penataan Barang-Barang Tidak Habis Pakai

Yaitu dengan cara mengatur barang yang ada dengan memberikan nomor dan kode pada barang tersebut sesuai dengan sandi yang berlaku. Hal ini dilakukan agar petugas dan pemakai lebih mudah memakai dan mengawasi pemakainnya. 


\section{Pengaruh Sarana dan Prasarana Pendidikan Dalam Menunjang Kualitas Siswa}

Bahwa kualitas pendidikan tersebut juga didukung dengan sarana dan prasarana yang menjadi standar sekolah atau instansi pendidikan terkait. Sarana prasarana sangat mempengaruhi kemampuan siswa dalam belajar. Hal ini menunjukkan bahwa peranan sarana dan prasarana sangat penting dalam menunjang kualitas belajar siswa.

Adapun hubungan sarana dan prasarana dengan proses pendidikan dapat dikatakan bahwa sarana dan prasarana pendidikan dapat didefinisikan sebagai proses kerja sama pendayagunaan semua sarana dan prasarana pendidikan secara efektif dan efisien. Definisi ini menunjukkan bahwa sarana dan prasarana yang ada di sekolah perlu didayagunakan dan dikelola untuk kepentingan proses pembelajaran di sekolah. karena keberadaannya akan sangat mendukung terhadap suksesnya proses pembelajaran di sekolah. Apa yang dibutuhkan oleh sekolah perlu direncanakan dengan cermat berkaitan dengan sarana dan prasarana yang mendukung semua proses pembelajaran.

\section{Pentingnya Sarana dan Prasarana Pendidikan}

Setiap mata pelajaran memiliki karakter yang berbeda dengan pelajaran lainnya. Dengan demikian, masing-masing mata pelajaran juga memerlukan sarana pembelajaran yang berbeda pula. Dalam menyelenggarakan pembelajaran guru pastinya memerlukan sarana yang dapat mendukung kinerjanya sehingga pembelajaran dapat berlangsung dengan menarik. Dengan dukungan sarana pembelajaran yang memadai, guru tidak hanya menyampaikan materi secara lisan, tetapi juga dengan tulis dan peragaan sesuai dengan sarana prasarana yang telah disiapkan guru.

Guru membutuhkan sarana pembelajaran dalam menunjang kegiatan pembelajaran. Selain kemampuan guru dalam menyelenggarakan kegiatan pembelajaran, dukungan dari sarana pembelajaran sangat penting dalam 
membantu guru. Semakin lengkap dan memadai sarana pembelajaran yang dimiliki sebuah sekolah akan memudahkan guru dalam melaksanakan tugasnya sebagai tenaga pendidikan.

Mengingat pentingnya sarana prasarana dalam kegiatan pembelajaran, maka peserta didik, guru dan sekolah akan terkait secara langsung. Peserta didik akan lebih terbantu dengan dukungan sarana prasarana pembelajaran. Tidak semua peserta didik mempunyai tingkat kecerdasan yang bagus sehingga penggunaan sarana prasarana pembelajaran akan membantu peserta didik, khususnya yang memiliki kelemahan dalam mengikuti kegiatan pembelajaran. Bagi guru akan terbantu dengan dukungan fasilitas sarana prasarana. Kegiatan pembelajaran juga akan lebih variatif, menarik dan bermakna. Sedangkan sekolah berkewajiban sebagai pihak yang paling bertanggung jawab terhadap pengelolaan seluruh kegiatan yang diselenggarakan. Selain menyediakan, sekolah juga menjaga dan memelihara sarana prasarana yang telah dimiliki. Sarana Prasarana yang perlu dalam Administrasi Pendidikan.

\section{Contoh Kegiatan Manajemen Sekolah : Manajemen Fasilitas}

\begin{tabular}{|l|l|l|l|}
\hline PERENCANAAN & PENGORGANISASIAN & PENGERAHAN & PENGAWASAN \\
\hline $\begin{array}{l}\text { Analisis kebutuhan } \\
\text { sarana prasarana } \\
\text { sekolah }\end{array}$ & $\begin{array}{l}\text { Pendistribusian sarana } \\
\text { prasarana }\end{array}$ & $\begin{array}{l}\text { Pemanfaatan } \\
\text { sarana prasarana } \\
\text { sekolah secara } \\
\text { efektif dan efisien }\end{array}$ & $\begin{array}{l}\text { Pemantauan } \\
\text { kinerja } \\
\text { penggunaan dan } \\
\text { pemeliharaan } \\
\text { sarana prasarana }\end{array}$ \\
\hline $\begin{array}{l}\text { Perencanaan dan } \\
\text { pengadaan sarana } \\
\text { prasaransa }\end{array}$ & $\begin{array}{l}\text { Penataan sarana } \\
\text { prasarana sekolah }\end{array}$ & $\begin{array}{l}\text { Pemeliharaan } \\
\text { sarana prasarana } \\
\text { sekolah }\end{array}$ & $\begin{array}{l}\text { Penilaian kinerja } \\
\text { penggunaan dan } \\
\text { pemeliharaan } \\
\text { sarana prasarana } \\
\text { sekolah }\end{array}$ \\
\hline $\begin{array}{l}\text { Perencanaan dan } \\
\text { pengadaan guru dan } \\
\text { pegawai baru }\end{array}$ & $\begin{array}{l}\text { Inventarisasi } \\
\text { sarana prasarana } \\
\text { sekolah }\end{array}$ & $\begin{array}{l}\text { Penghapusan } \\
\text { sarana prasarana }\end{array}$ \\
\hline \multicolumn{2}{|l|}{} & & \\
\hline
\end{tabular}

Sumber : Manajemen Sekolah. Sulfemi, Wahyu Bagja. 2019 


\section{BAB IV \\ SOAL DAN JAWABAN}

\section{A. Pilihan Ganda}

1. Manajemen adalah proses bekerja sama antara individu dan kelompok serta sumber daya lainnya dalam mencapai tujuan organisasi adalah sebagai aktivitas majerial.
a. Rohiat
b. Santoso
c. Wahyu Bagja Sulfemi
d. Aries Toteles

2. ......... Suatu proses kegiatan menggambarkan sebelumnya hal-hal yang akan dikerjakan kemudian dalam rangka mencapai tujuan yang telah ditetapkan.
a. Perencaan
b. Pengadaan
c. Pemeliharaan
d. Penghapusan

3. Kegiatan manajemen sarana dan prasarana pendidikan meliputi......
a. Perencanaan, Pemusnahan, Penghitungan, dan Penghapusan
b. Pengadaan, Penghapusan, Pemecahan, dan Pemeliharaan
c. Pemusnahan, Perencanaan, Pengadaan, dan Penghapusan
d. Perencanaan, Pengadaan, Penyimpanan, Pemeliharaan, dan Penghapusan

4. Sarana pendidikan diklasifikasikan menjadi tiga macam, yaitu.....
a. Habis tidaknya dipakai, bergerak tidaknya pada saat digunakan, dan ditinjau dari hubungannya dengan proses belajar mengajar.
b. Habis karena dipakai, rusak karena dipakai, dan bermanfaat dalam proses belajar mengajar.
c. Sarana habis pakai, sarana bergerak, dan sarana tidak bergerak.
d. Habis tidaknya dipakai, berguna bagi belajar, dan sarana bergerak. 
5. Sarana pendidikan yang tahan lama, contohnya adalah.....
a. Kapur Tulis
b. Isi Spidol
c. Bahan Kimia
d. Bangku Sekolah

6. Almari arsip sekolah termasuk ke dalam benda.....
a. Tidak Bergerak
b. Bergerak
c. Tetap
d. Tidak Tetap

7. Dalam proses belajar mengajar diperlukan sebuah media pengajaran, diantaranya adalah.....
a. Audio
b. Visual
c. Audio Visual
d. Jawaban a, b, dan c benar

8. Jalan menuju sekolah, kamar kecil, kantin dan ruang kantor. Termasuk ke dalam.....
a. Sarana
b. Prasarana
c. Sarana dan Prasarana
d. Ruang Luar

9. "Kegiatan yang dilakukan untuk menampung hasil pengadaan dan umumnya barang tersebut adalah milik negara pada wadah/tempat yang telah disediakan”.

Pengertian di atas merupakan pengelolaan saran dan prasarana pendidikan dari....
a. Perencanaan
b. Penataan
c. Penyimpanan
d. Penghapusan 
10. Di dalam pembelajaran, sarana dan prasarana ditinjau sangat penting, karena masing-masing mata ppelajaran memerlukan sarana pembelajaran yang berbeda-beda pula. Maka yang terkait langsung dalam hal sarana prasarana adalah....
a. Peserta Didik, Guru, dan Sekolah
b. Penjaga Sekolah, Satpam
c. Guru, dan Kepala Sekolah
d. Peserta Didik dan Orang Tua

\section{B. Essay}

1. Apa yang dimaksud dengan manajemen sarana dan prasaran pendidikan?

2. Apa perbedaan sarana dengan prasarana ?

3. Seberapa penting sarana dan prasarana memenuhi kegiatan belajar mengajar?

4. Berikan contoh benda yang habis tidak di pakai, masing-masing dua contoh.

5. Bagaimana caranya untuk menentukan kebutuhan sarana dan prasarana dalam perencanaan?

\section{Jawaban}

\section{a. Pilihan Ganda}

1. $\mathrm{C}$

6. B

2. A

7. D

3. D

8. B

4. A

9. C

5. D

10. A

\section{b. Essay}

1. Manajemen Sarana dan Prasarana pendidikan adalah kegiatan yang mengatur untuk mempersiapkan segala peralatan/material bagi terselenggaranya proses pendidikan di sekolah. Manajemen 
sarana dan prasarana dibutuhkan untuk membantu kelancaran proses belajar mengajar.

2. Sarana pendidikan adalah untuk memudahkan dalam penyampaian materi ajar, dalam artian segala macam peralatan yang digunakan guru dan murid untuk memudahkan penyampaian dan penerimaan materi pelajaran. Sedangkan prasarana pendidikan adalah untuk memudahkan penyelenggaraan pendidikan dalam artian segala macam peralatan, kelengkapan, dan benda-benda yang digunakan guru dan murid untuk memudahkan penyelenggaraan pendidikan.

3. Penting sekali. Karena, setiap mata pelajaran memiliki karakter yang berbeda dengan pelajaran lainnya. Dengan demikian, masing-masing mata pelajaran juga memerlukan sarana pembelajaran yang berbeda pula. Dalam menyelenggarakan pembelajaran guru pastinya memerlukan sarana yang dapat mendukung kinerjanya sehingga pembelajaran dapat berlangsung dengan menarik. Dengan dukungan sarana pembelajaran yang memadai, guru tidak hanya menyampaikan materi secara lisan, tetapi juga dengan tulis dan peragaan sesuai dengan sarana prasarana yang telah disiapkan guru.

4. Sarana pendidikan yang habis dipakai :

- Kapur Tulis

- Bahan Kimia

Sarana pendidikan tahan lama :

- Bangku Sekolah

- Mesin Tulis

5. Sebelum mengadakan alat-alat tertentu atau fasilitas pendidikan terlebih dahulu harus melalui prosedur yang benar, yaitu melihat dan memeriksa kembali keadaan dan kekayaan yang telah ada, agar tidak terjadi sarana pendidikan yang mubazir, seperti pengadaan kembali sarana yang masih memadai dari segi kuantitas maupun kualitas atau pengadaan alat-alat yang tidak diperlukan 
dalam penyelenggaraan pendidikan. Setelah melalui prosedur yag benar, baru bisa ditentukan jenis sarana yang diperlukan berdasarkan kepentingan pendidikan di sekolah. 


\section{BAB V \\ PENUTUP}

\section{A. Kesimpulan}

Prasarana pendidikan merupakan semua komponen yang secara tidak langsung menunjang jalannya proses belajar mengajar di sekolah atau perangkat kelengkapan dasar yang secara tidak langsung yang menunjang proses pendidikan di sekolah. Sedangkan sarana adalah semua perangkat peralatan, bahan dan perabot yang secara langsung digunakan dalam proses pendidikan atau alat langsung untuk mencapai tujuan pendidikan.

Fungsi fasilitas atau sarana prasarana pendidikan adalah membuat siswa merasa nyaman dan dapat memotivasi siswa dalam belajar, sehingga proses belajar dapat berjalan dengan lancar dan berhasil sesuai yang diharapkan yaitu dapat meningkatkan prestasi siswa.

\section{B. Saran}

1. Saya menyadari sepenuhnya bahwa didalam makalah ini terdapat kekurangan dan jauh dari kata sempurna. Oleh sebab itu, saya berharap kritik, saran dan usulan demi perbaikan makalah yang telah penulis buat di waktu yang akan datang.

2. Kepada dosen pengampu Bapak Wahyu Bagja Sulfemi, M.Pd yang telah memberikan pengetahuannya kepada saya, saya sangat menyadari bahwa makalah ini jauh dari kesempurnaan. Oleh karenanya, kritik dan saran sangat saya harapkan demi kesempurnaan makalah ini.

3. Kepada teman-teman saya mengharap adanya masukan, kritik dan saran yang membangun. 


\section{Daftar Pustaka}

http://hamasbinsyukri.blogspot.com/2017/08/maklah-sarana-dan-prasaranapendidikan.html

http://makalahastri.blogspot.com/2016/01/sarana-dan-prasaranapendidikan.html?m=1

https://www.padamu.net/pengertian-sarana-dan-prasaran-pendidikan

Rohiat. (2010). Manajemen Sekolah. Bandung : PT Refika Aditama.

Sulfemi, Wahyu Bagja dan Hilga Minati. (2018). Meningkatkan Hasil Belajar Peserta Didik Kelas 3 SD Menggunakan Model Picture And Picture dan Media Gambar Seri. JPSD. 4 (2), 228- 242.

Sulfemi, Wahyu Bagja. (2018). Modul Manajemen Pendidikan Non Formal. Bogor: STKIP Muhammadiyah Bogor.

Sulfemi, Wahyu Bagja. (2018). Manajemen Kurikulum di Sekolah. Bogor : Visi Nusantara Maju.

Sulfemi, W. B. (2019). Manajemen Pendidikan Berbasis Multi Budaya. Bogor : STKIP Muhammadiyah Bogor.

Sulfemi, Wahyu Bagja. (2019). Manajemen Sekolah. Bogor : Program Studi Administrasi Pendidikan STKIP Muhammadiyah Bogor. 